\title{
$J M M$ UNRAM

\section{PENGARUH EKUITAS MEREK DAN KUALITAS PELAYANAN TERHADAP MINAT BELI ULANG KONSUMEN AXA MANDIRI MAPAN SEJAHTERA DI KOTA MATARAM}

\author{
Baiq Dinna Widiyasti ${ }^{1)}$ \\ Budi Santoso 2) \\ Rusdan ${ }^{3)}$
}

\begin{abstract}
The objective of the study was to evaluate the influence of brand equity and service quality toward consumer repurchase intention of AXA Mandiri Mapan Sejahtera's insurance in the city of Mataram. Associative research design was adopted as the study guide. Purposive sampling techniques were used in which 97 copies of the research instrument were administered to consumer of AXA Mandiri Mapan Sejahtera's, city of Mataram, out of which 97 copies of questionnaire were filled and returned. Pearson Product Moment correlation was used to analyse the data generated from respondents. The findings revealed that brand equity and service quality have significant influence on consumer repurchase intention at 0,05 level (2-tailed). The result of the research shows both of the variables significantly affecting consumer repurchase intention. Furthermore, brand equity ranks the first follow by service quality. This research will help the management of insurance to understand and recognize the ranking of variables affecting consumer repurchase intention of AXA Mandiri Mapan Sejahtera's insurance.
\end{abstract}

Keywords: Insurance, Brand Equity, Service Quality, and Repurchase Intention.

\section{Pendahuluan}

Krisis keuangan, meningkatnya biaya kesehatan, pendidikan dan kebutuhan di usia pensiun, semakin meningkatkan kesadaran masyarakat untuk berinvestasi dan memproteksi diri dengan membeli produk asuransi (Yuniarti, 2009). Meningkatnya minat masyarakat terhadap produk asuransi diikuti dengan semakin selektifnya masyarakat dalam memilih perusahaan asuransi, ini dilakukan masyarakat untuk mendapatkan jaminan produk proteksi yang berkualitas dan terhindar dari persoalan finansial.

Asuransi merupakan produk dengan manfaat yang tidak dapat dirasakan langsung manfaatnya dibutuhkan kepercayaan dan kualitas pelayanan yang tinggi untuk meningkatkan nilai persaingan pasarnya. Sebagaimana perusahaan lainnya, loyalitas konsumen terhadap perusahaan asuransi akan berpengaruh bagi peningkatan kesuksesan penjualannya. Konsumen cenderung untuk membeli dan menggunakan, bahkan melakukan pembelian ulang untuk produk atau jasa perusahaan. Konsumen yang memiliki loyalitas yang tinggi dapat dilihat dari penggunaan suatu produk atau jasa tertentu secara terus-menerus meskipun terdapat layanan produk dan jasa pesaing yang ditawarkan dengan harga dan kenyamanan yang lebih baik.

Salah satu strategi yang dapat dilakukan dalam membentuk hubungan jangka panjang antara perusahaan dengan konsumen adalah dengan membangun dan mengelola ekuitas merek secara tepat (Durianto, 2004). Loyalitas konsumen akan terbangun ketika terdapat kepercayaan konsumen terhadap perusahaan dan kualitas layanan yang memuaskan dari perusahaan terhadap konsumen. Konsumen yang percaya terhadap suatu 


\section{JMM UNRAM \\ JURNAL MAGISTER MANAJEMEN \\ UNIVERSITAS MATARAM \\ September 2016}

perusahaan maka konsumen tersebut akan memiliki keyakinan terhadap keahlian perusahaan tersebut untuk dapat melayani secara baik, memuaskan dan dapat diandalkan.

Strategi pemasaran produk asuransi salah satunya dilakukan dengan kerja sama pemasaran antara perusaahaan perbankan dengan asuransi melalui produk bancasurrance. Awalnya bancasurrance berkembang di Prancis awal tahun 1990-an dan secara umum bagi masyarakat bancasurrance adalah praktek menjual produk asuransi melalui bank. Bank dapat menjual produk asuransi sebaliknya perusahaan asuransi dapat menjual produk bank, dan kerjasama ini diharapkan bisa meningkatkan kinerja perusahaan.

Perkembangan bancasurrance di Indonesia saat ini juga semakin meningkat, banyak bank di Indonesia menawarkan produk bancasurrance baik berupa produk bank yang ada asuransinya maupun produk asuransi yang melibatkan bank. Seperti halnya pada tahun 2003, dimana Bank Mandiri bekerja sama dengan AXA group untuk sebuah bancasurrance bernama AXA Mandiri. Kerja sama ini melibatkan dua perusahaan dengan nama besar dan handal dengan harapan bagi keduanya tentu memperoleh kinerja terbaik dan menguasai pasar. Menurut Berry (2000) dalam Chan (2010), perusahaan jasa yang bersifat intangible menyebabkan peranan merek yang mempunyai ekuitas yang kuat akan meningkatkan kepercayaan konsumen untuk menggunakan jasa tersebut.

Tahun 2012 AXA mandiri mengalami pertumbuhan laba bersih dan aset perusahaan yang semakin memperkuat kondisi kesehatan keuangannya, terlihat dari rasio kecukupan modal yang telah memperhitungkan aspek risiko 368 persen untuk portofolio konvensional dan mencapai 81 persen untuk dana tabarru' dari portofolio syariah (Detik Finance, 2013). Hal ini juga diiringi oleh tingkat penjualan produk AXA Mandiri di kota Mataram khususnya, sebagaimana dapat dilihat berdasarkan laporan penjualan AXA Mandiri Kota Mataram tahun 2011 hingga tahun 2014, dimana terdapat peningkatan penjualan polis AXA Mandiri Sejahtera rata-rata sebesar 114 polis tiap tahunnya. Dengan jumlah pegawai Financial Advisor (FA) yang jumlahnya rata-rata 10 orang, hal ini dirasakan cukup besar dan menguntungkan dari segi penilaian kinerja perusahaan. Diketahui bahwa volume penjualan polis yang dilakukan oleh AXA Mandiri Sejahtera Mapan Kota Mataram periode 2011-2014 selalu mengalami peningkatan dengan rata-rata sebesar 19 persen per tahun.

Perkembangan kehidupan masyarakat daerah Mataram saat ini juga mulai menyadari pentingnya menghindari risiko ataupun mengatasi risiko yang akan terjadi. Bagi pengusaha, perlindungan dibutuhkan untuk mengurangi dampak risiko yang bisa terjadi kemudian pada masyarakat umum. Pada tingkatan keluarga atau rumah tangga, asuransi juga dibutuhkan untuk mengurangi permasalahan ekonomi yang akan dihadapi apabila salah satu anggota keluarga terutama yang memiliki nilai ekonomi tinggi mengalami risiko cacat atau meninggal dunia.

AXA Mandiri meningkatkan layanan serta inovasi produknya untuk terus dapat memenuhi kebutuhan konsumen, salah satunya dengan terus berinovasi untuk produk asuransi unit link yang dimilikinya yaitu Mandiri Sejahtera Mapan. Produk asuransi ini merupakan produk asuransi jiwa dengan manfaat tambahan investasi unit reksadana yang banyak diminati konsumen Mereka mengalokasikan dananya untuk menjaga mereka dari risiko yang mungkin terjadi, sekaligus berinvestasi dalam reksadana perusahaan tersebut.

Pemasaran serta penanganan after sales produk AXA Mandiri dilakukan di dalam Bank Mandiri seluruh Indonesia, sehingga nasabah AXA Mandiri ketika melakukan berbagai transaksi produk asuransi yang dimilikinya akan lebih mudah. Pada kondisi 


\section{$J M M$ UNRAM

tertentu, pemegang polis mengalami risiko tidak pada tempat mereka membuka produk asuransi AXA Mandirinya yang pertama kali, mereka dapat melakukan administrasi klaim risiko ataupun administrasi lainnya secara cepat di cabang Bank Mandiri yang terdekat dengan mereka. Penanganan transaksi pemegang polis merupakan kewajiban seluruh staf AXA Mandiri di seluruh cabang Bank Mandiri untuk membantunya. Dengan demikian seluruh nasabah AXA Mandiri akan memperoleh kenyamanan atas produk asuransi yang mereka telah miliki.

Tujuan penelitian ini adalah untuk menganalisis pengaruh ekuitas merek dan kualitas pelayanan terhadap minat beli ulang konsumen AXA Mandiri Mapan di kota Mataram.

\section{Tinjauan Teori}

\subsection{Minat Beli Ulang Konsumen}

Menurut Hellier et al., (2003) dalam Yaqian (2011), niat beli ulang didefinisikan sebagai penilaian individu tentang membeli lagi layanan yang ditunjuk di perusahaan yang sama, dengan mempertimbangkan situasinya saat ini dan keadaan yang memungkinkan. Sedangkan menurut Anoraga (2000:228) repurchase intention merupakan suatu proses pengambilan keputusan yang dilakukan oleh konsumen sesudah mengadakan pembelian atas produk yang ditawarkan atau yang dibutuhkan oleh konsumen tersebut.

Mowen dan Minor (1998) mengatakan bahwa perilaku pembelian ulang memiliki arti bahwa pelanggan membeli secara berulang terhadap produk tertentu. Johnson (1998) mengatakan bahwa proses informasi dan komponen kepuasan secara bersama-sama akan menjadi elemen yang penting dalam siklus pembelian ulang.

Minat pembelian ulang adalah keinginan yang timbul dalam diri pelanggan untuk membeli kembali produk atau jasa di masa datang setelah sebelumnya pernah mengkonsumsi produk atau jasa yang sama. Dalam penelitian yang dilakukan Adhi (2009), minat beli ulang dilihat dari:

1) Kebutuhan konsumen akan produk perusahaan,

2) Keinginan konsumen membeli ulang produk,

3) Ketertarikan konsumen untuk tetap menggunakan produk perusahaan.

Taylor dan Cosenza (2002) yang menyatakan bahwa perilaku pembelian ulang yang dilakukan pelanggan banyak dipengaruhi oleh beberapa hal di antaranya merek produk dan layanan yang diberikan oleh perusahaan.

Repurchase Intentions merupakan tindakan konsumen pasca pembelian. Terjadinya kepuasan dan ketidakpuasan pasca pembelian konsumen terhadap suatu produk akan mempengaruhi perilaku selanjutnya. Jika konsumen puas, maka akan menunjukkan kemungkinan yang lebih tinggi untuk membeli kembali produk tersebut (Kotler, 1995).

Faktor-faktor yang mempengaruhi minat beli ulang adalah kepuasan konsumen atas produk perusahaan, kemudahan konsumen memperoleh informasi mengenai manfaat produk yang akan yang akan mereka dapatkan, dan citra merek dan harga produk perusahaan.

\subsection{Ekuitas Merek}

Menurut Aaker (1997) ekuitas merek adalah seperangkat aset dan liabilitas yang terkait dengan suatu merek, nama dan simbol yang mampu menambah atau mengurangi nilai yang diberikan oleh sebuah produk atau jasa baik pada perusahaan ataupun pada 
pelanggan. Menurut Retnawati (2003), merek menjadi sangat strategis bagi perusahaan dikarenakan adanya manfaat yang diberikan bagi penjual dan pembeli.

Selanjutnya menurut Aaker (1997) ekuitas merek dapat dikelompokkan dalam lima kategori, yaitu:

1) Kesadaran merek, menunjukkan kesanggupan seorang calon pembeli untuk mengenali atau mengingat kembali bahwa suatu merek merupakan bagian dari kategori produk tertentu. Kesadaran merek membutuhkan jangkauan kontinum (Continum Ranging) dari perasaan yang tak pasti bahwa merek tertentu dikenal menjadi keyakinan bahwa produk tersebut merupakan satu-satunya dalam kelas produk bersangkutan, kontinum ini dapat diwakili oleh tingkat kesadaran merek yang berbeda.

2) Loyalitas merek, mencerminkan tingkat keterikatan konsumen dengan suatu merek produk. Ukuran ini mampu memberikan gambaran tentang mampu tidaknya seorang pelanggan beralih ke merek produk lain. Bila loyalitas terhadap suatu merek meningkat, kerentanan terhadap serangan pesaing dapat dikurangi.

3) Kesan kualitas, menunjukkan persepsi pelanggan terhadap keseluruhan kualitas/keunggulan suatu produk atau jasa layanan yang sama dengan apa yang diharapkan oleh pelanggan.

4) Asosiasi merek dapat menciptakan nilai bagi perusahaan dan para pelanggan, karena ia dapat membantu proses penyusunan informasi untuk membedakan merek yang satu dengan merek lainnya. Berbagai asosiasi yang diingat konsumen dapat menghasilkan suatu bentuk citra tentang merek (brand image) di benak konsumen. Asosiasi merek adalah segala hal yang berkaitan dengan ingatan mengenai merek. Konsumen yang terbiasa menggunakan merek tertentu cenderung memiliki konsistensi terhadap citra merek (brand image) yang disebut juga dengan kepribadian merek (brand personality) yang kemudian dapat membentuk kesetiaan konsumen terhadap merek tertentu (brand loyalty).

\subsection{Kualitas Pelayanan}

Setiap organisasi modern dan maju senantiasa mengedepankan bentuk-bentuk aktualisasi kualitas layanan. Kualitas layanan yang dimaksud adalah memberikan bentuk pelayanan yang optimal dalam memenuhi kebutuhan, keinginan, harapan dan kepuasan dari masyarakat yang meminta pelayanan dan yang meminta dipenuhi pelayanannya. Parasuraman (2001:26) mengemukakan konsep kualitas layanan yang berkaitan dengan kepuasan ditentukan oleh lima unsur antara lain: responsiveness, assurance, tangible, empathy dan reliability. Konsep ini intinya adalah membentuk sikap dan perilaku dari pengemban pelayanan untuk memberikan bentuk pelayanan yang kuat dan mendasar, agar mendapat penilaian sesuai dengan kualitas layanan yang diterima.

Menurut Parasuraman et al., (1988), sepuluh dimensi service quality yang dihasilkan dari penelitian sebelumnya ditemukan intisari dari kualitas layanan yang dilebur menjadi lima dimensi dari service quality, yaitu:

1) Reliability (keandalan), kemampuan melaksanakan layanan yang dijanjikan secara meyakinkan dan akurat.

2) Responsiveness (ketanggapan), kesediaan membantu konsumen dan memberikan jasa dengan cepat.

3) Assurance (jaminan), pengetahuan dan kesopanan serta kemampuan mereka menyampaikan kepercayaan dan keyakinan. 


\section{JMM UNRAM

4) Empathy (empati), kesediaan memberikan perhatian yang mendalam dan khusus kepada masing-masing konsumen.

5) Tangibles (benda berwujud), penampilan fisik, perlengkapan, karyawan dan bahan komunikasi.

\subsection{Hubungan Ekuitas Merek terhadap Minat Beli Ulang}

Fihartini (2009) dalam penelitiannya membuktikan kepercayaan berpengaruh positif terhadap loyalitas pelanggan, sehingga upaya untuk mempertahankan nasabah bagi manajer perusahaan asuransi akan dapat diwujudkan dengan variabel kepercayaan yang juga berpengaruh bagi tingkat pembelian yang dilakukan konsumen teerhadap produk perusahaan. Selanjutnya brand equity berpengaruh terhadap brand preference dan purchase intention, brand preference yang memediasi hubungan antara brand equity terhadap purchase intention sebagaimana hasil penelitian Edwin Sanjaya (2009).

H1 : Ekuitas merek berpengaruh terhadap minat beli ulang konsumen AXA Mandiri Mapan.

\subsection{Hubungan Kualitas Pelayanan terhadap Minat Beli Ulang}

Penelitian Ratih (2009) mengungkapkan persepsi pelanggan mengenai kinerja perusahaan yang terdiri dari kinerja produk, kinerja pelayanan dan kinerja sumber daya manusia mempengaruhi niat pembelian ulang polis asuransi jiwa melalui kepuasan nasabah. Persepsi pelanggan terhadap kinerja produk, kinerja pelayanan dan kinerja sumber daya manusia tidak berpengaruh terhadap niat pembelian ulang melalui citra perusahaan. Akan tetapi citra perusahaan dapat mempengaruhi niat pembelian ulang melalui kepuasan pelanggan.

H2: Kualitas pelayanan berpengaruh terhadap minat beli ulang konsumen AXA Mandiri Mapan.

\subsection{Hubungan Kualitas Pelayanan dan Ekuitas Merek terhadap Minat Beli Ulang}

Darwin dan Kunto (2014) dalam penelitiannya membuktikan kualitas layanan berpengaruh signifikan terhadap kepuasan pelanggan dan kepercayaan pelanggan, kepuasan pelanggan berpengaruh signifikan terhadap loyalitas pelanggan, kepercayaan pelanggan berpengaruh signifikan terhadap loyalitas pelanggan, sehingga diharapkan dapat terus bertumbuh dan berkembang dengan terus mengacu pada variabel kualitas layanan, kepuasan, kepercayaan, dan loyalitas pelanggan agar dapat bersaing dengan kompetitornya.

Begitu juga halnya dengan penelitian yang dilakukan Fihartini (2009), dalam penelitiannya membuktikan kualitas layanan dan kepercayaan berpengaruh positif terhadap loyalitas pelanggan, sehingga upaya untuk mempertahankan nasabah bagi manajer perusahaan asuransi akan dapat diwujudkan dengan memperhatikan kualitas layanan dan kepercayaan nasabah.

H3 : Ekuitas merek dan kualitas pelayanan secara bersama-sama (simultan) berpengaruh terhadap minat beli ulang konsumen AXA Mandiri Mapan.

\subsection{Kerangka Konseptual}

Berdasarkan pemikiran di atas, maka dapat digambarkan sebuah kerangka pemikiran penelitian seperti pada gambar berikut: 


\section{TMU JURAL MAGISTER MANAJEMEN UNIVERSITAS MATARAM \\ September 2016

\section{Gambar 1}

Kerangka Konseptual Penelitian

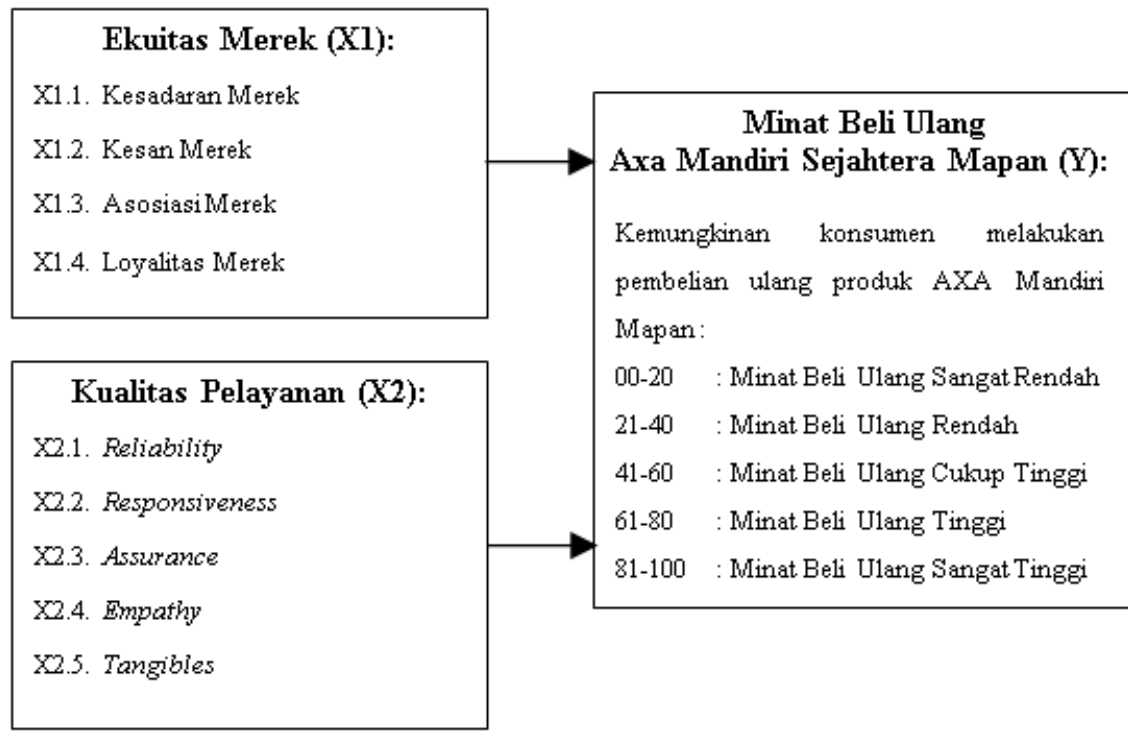

\section{Metode Penelitian}

Penelitian ini adalah penelitian asosiatif, yaitu suatu penelitian yang bertujuan untuk mengetahui hubungan antara dua variabel atau lebih (Sugiyono, 2006:11). Penelitian ini menganalisis pengaruh Ekuitas Merek dan Kualitas Pelayanan terhadap Minat Beli Ulang Konsumen AXA Mandiri Sejahtera Mapan di Kota Mataram, dimana hubungan antara variabel dalam penelitian akan dianalisis dengan menggunakan ukuran-ukuran statistika yang relevan atas data tersebut untuk menguji hipotesis penelitian.

Populasi merupakan keseluruhan objek penelitian atau objek yang diteliti (Notoatmodjo, 2010). Populasi dalam penelitian ini adalah nasabah AXA Mandiri di kota Mataram pada tahun 2011 hingga 2014 yang berjumlah 4.139 nasabah. Sampel dalam penelitian ini ditentukan menggunakan rumus Slovin yang dikutip oleh Notoatmodjo (2010). Dalam penelitian ini, teknik pengambilan sampel yang digunakan adalah nonprobability sampling dengan menggunakan purposive sampling, dimana responden sampel pada penelitian ini adalah nasabah AXA Mandiri di kota Mataram yang memiliki polis AXA Mandiri Mataram Mapan.

Teknik analisis data yang digunakan adalah analisis regresi linier berganda, namun terlebih dahulu dilakukan uji kualitas instrumen dan uji asumsi klasik. Untuk memudahkan di dalam menggunakan alat analisis statistik regresi linier berganda, maka digunakan bantuan aplikasi SPSS dalam komputer.

\section{Analisis Data dan Pembahasan}

\subsection{Uji Asumsi Klasik}

Evaluasi ini dimaksudkan untuk apakah penggunaan model regresi linier berganda (multiple regression linear) dalam menganalisis telah memenuhi asumsi klasik. Model linier berganda akan lebih tepat digunakan dan menghasilkan perhitungan yang lebih akurat apabila asumsi-asumsi berikut dapat terpenuhi yaitu: 
1) Uji Normalitas Data

Pengujian Normalitas digunakan untuk menguji apakah dalam sebuah model regresi, variabel terikat, variabel bebas atau keduanya mempunyai distribusi normal ataukah tidak. Model regresi yang baik adalah distribusi data normal atau mendekati normal. Hasil uji normalitas dapat dilihat pada gambar berikut ini:

\section{Gambar 2}

Hasil Pengujian Normalitas Data

Dependent Variable: $Y$

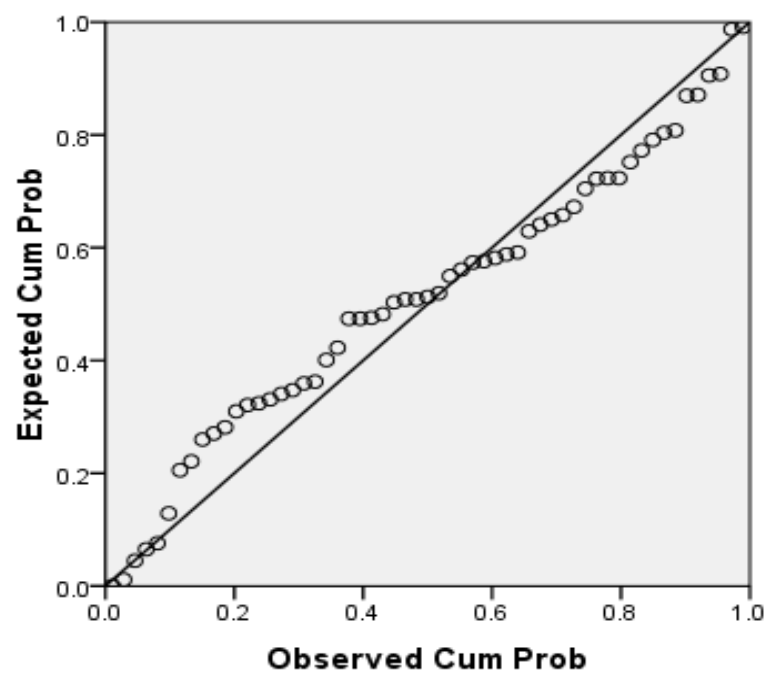

Sebagaimana terlihat dalam grafik Normal P-P Plot of Regression Standardized Residual, terlihat bahwa titik-titik menyebar di sekitar garis diagonal, serta penyebarannya mengikuti arah garis diagonal (membentuk garis lurus), maka dapat dikatakan bahwa data berdistribusi normal dan model regresi layak dipakai untuk memprediksi Minat Beli Ulang berdasarkan variabel bebasnya.

2) Uji Multikolinieritas Data

Uji multikolinieritas yaitu untuk mengetahui multikolinieritas antar variabel bebas tersebut, dapat dilihat melalui VIF (variance inflation factor) dari masing-masing variabel bebas terhadap variabel terikat. Apabila nilai VIF tidak lebih dari 5 berarti mengindikasi bahwa dalam model tidak terdapat multikolinieritas. Adapun hasil pengujian teringkas dalam tabel berikut:

Tabel Hasil Uji Multikolinieritas Variabel Bebas

\begin{tabular}{lccc}
\hline Variabel Bebas & Tolerance & VIF & $\begin{array}{c}\text { Keputusan } \\
\text { Asumsi } \\
\text { Multikolinieritas }\end{array}$ \\
\hline Ekuitas Merek $\left(\mathrm{X}_{1}\right)$ & 0,882 & 1,133 & Terpenuhi \\
Kualitas Pelayanan $\left(\mathrm{X}_{2}\right)$ & 0,882 & 1,133 & Terpenuhi \\
\hline
\end{tabular}

Sumber: Data Primer. 


\section{$J M M$ UNRAM

Pada tabel di atas terlihat bahwa kedua variabel bebas memiliki besaran angka VIF di sekitar angka 1 (Ekuitas Merek = 1,133 dan Kualitas Pelayanan =1,133), besaran angka tolerance semuanya mendekati angka 1 (Ekuitas Merek $=0,882$ dan Kualitas Pelayanan $=0,882$ ), sehingga dapat disimpulkan bahwa tidak terjadi multikolinieritas antara kedua variabel bebas dan model regresi layak digunakan.

3) Uji Heterokedastisitas Data

Tujuan dari pengujian ini adalah untuk menguji apakah dalam sebuah model regresi, terjadi ketidaksamaan varians dari residual satu pengamatan ke pengamatan yang lain. Jika varians dari residual satu pengamatan ke pengamatan yang lain tetap, maka disebut homoskedastisitas, dan jika varians berbeda, disebut heteroskedastisitas. Model regresi yang baik adalah tidak terjadi heteroskedastisitas. Hasil pengujian ditunjukkan dalam gambar berikut:

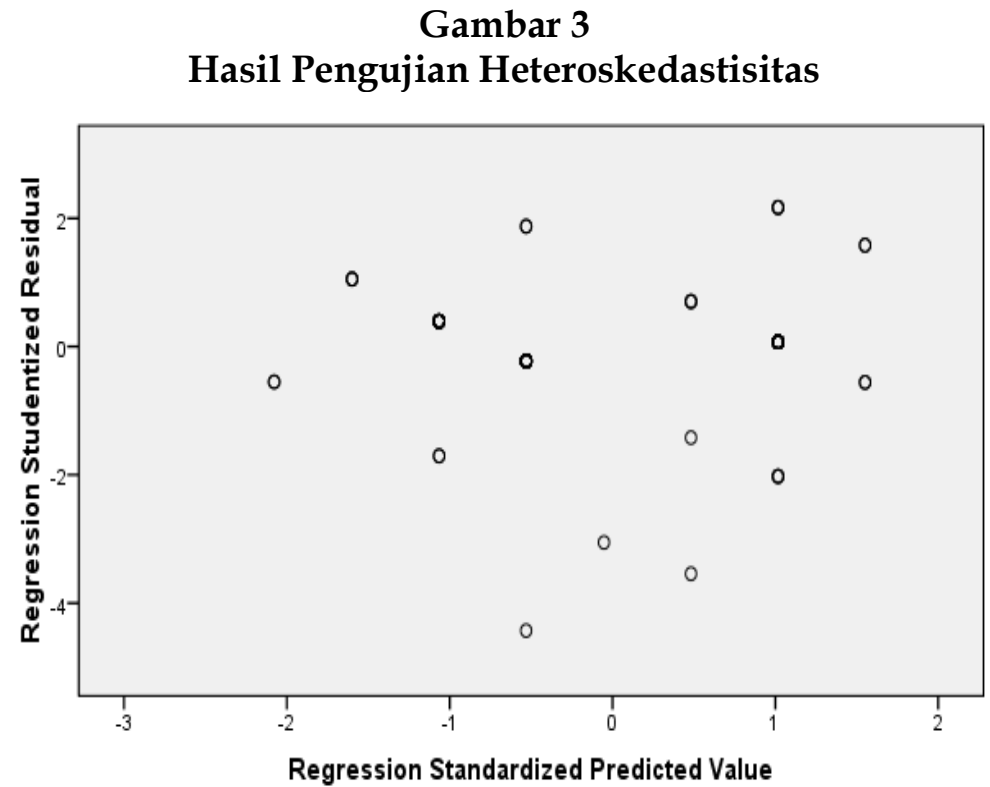

Dari grafik Scatterplot tersebut, terlihat titik-titik menyebar secara acak dan tidak membentuk suatu pola tertentu yang jelas, serta tersebar baik di atas maupun di bawah angka 0 pada sumbu Y. Hal ini berarti tidak terjadi heretoskedastisitas pada model regresi, sehingga model regresi layak dipakai untuk memprediksi minat beli ulang berdasar masukan variabel independennya.

4) Uji Autokorelasi Data

Secara umum, deteksi adanya autokorelasi dapat memperhatikan ketentuan sebagai berikut:

a) 1,67 < DW $<2,33$ tidak terjadi autokorelasi.

b) $1,47 \leq \mathrm{DW} \leq 1,67$ atau $2,33 \leq \mathrm{DW} \leq 2,53$ tidak dapat disimpulkan.

c) $\mathrm{DW}<1,67$ atau DW $>2,33$ terjadi autokorelasi. 
Tabel Hasil Uji Autokkorelasi Durbin-Waston $X_{1}, X_{2}$, terhadap $Y$

\begin{tabular}{ccccccc}
\hline Model & $\mathbf{R}$ & $\begin{array}{c}\boldsymbol{R} \\
\text { Square }\end{array}$ & $\begin{array}{c}\text { Adjusted } \boldsymbol{R} \\
\text { Square }\end{array}$ & $\begin{array}{c}\text { Std. Error of } \\
\text { the } \\
\text { Estimate }\end{array}$ & $\begin{array}{c}\text { Durbin- } \\
\text { Watson }\end{array}$ & Kesimpulan \\
\hline $\begin{array}{c}0,75 \\
8\end{array}$ & 0,574 & 0,565 & 0,48217 & 2,284 & $\begin{array}{c}\text { Tidak ada } \\
\text { Autokorelasi }\end{array}$ \\
\hline
\end{tabular}

Sumber: Data Primer.

Berdasarkan tabel di atas didapat nilai DW sebesar 2,284. Nilai DW menurut tabel dengan $\mathrm{n}=97$ dan $\mathrm{k}=2$ didapat angka $\mathrm{dL}=1,6275$ dan $\mathrm{dU}=1,7116$. Oleh karena nilai DW hitung $>$ dU dan < (4-dU) maka dapat disimpulkan tidak terdapat autokorelasi antar residual.

\subsection{Analisis Regresi Linear Berganda}

Dari analisis sebelumnya telah terbukti bahwa model persamaan yang diajukan dalam penelitian ini telah memenuhi persyaratan asumsi klasik sehingga model persamaan dalam penelitian ini sudah dianggap baik. Analisis regresi digunakan untuk menguji hipotesis tentang pengaruh secara parsial variabel bebas terhadap variabel terikat. Berdasarkan estimasi regresi berganda dengan program SPSS diperoleh hasil seperti tabel berikut:

Tabel Hasil Uji Regresi Linier Berganda Ekuitas Merek dan Kualitas Pelayanan

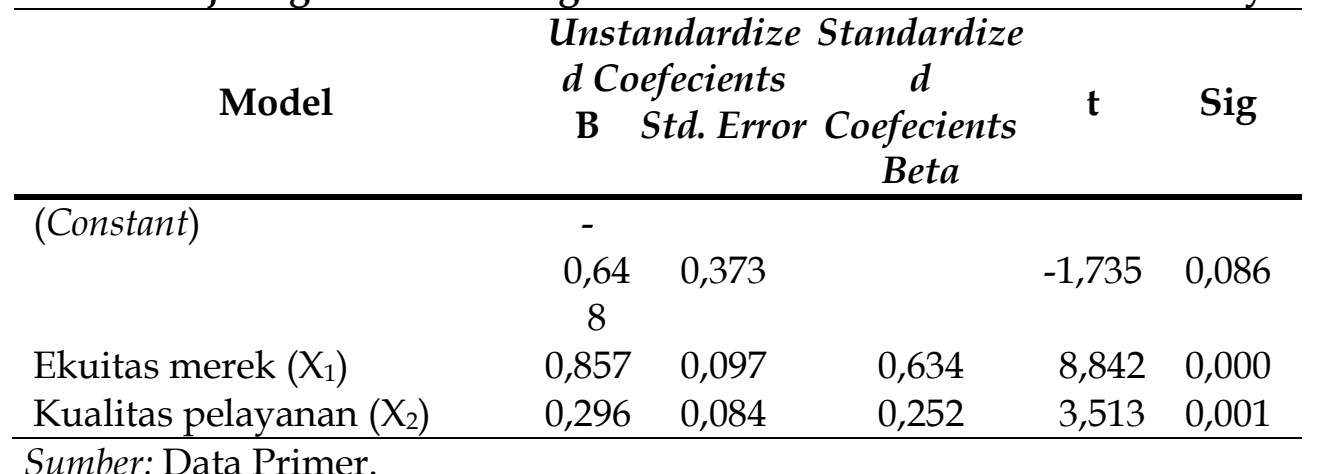

Berdasarkan tabel di atas dapat diketahui persamaan regresi bentuk Beta (B) yang terbentuk adalah:

$$
Y=-0,648+0,857\left(X_{1}\right)+0,296\left(X_{2}\right)
$$

Dari persamaan tersebut dapat dijelaskan bahwa:

1) Jika variabel $X_{1}$, dan $X_{2}$ tidak berubah/tetap maka tingkat minat beli ulang rendah yaitu $-0,648$.

2) Jika ekuitas merek semakin baik dengan asumsi variabel lain tetap maka minat beli ulang polis AXA Mandiri akan mengalami peningkatan.

3) Jika kualitas pelayanan semakin baik dengan asumsi variabel lain tetap maka minat beli ulang polis AXA Mandiri akan mengalami peningkatan. 


\section{$J M M$ UNRAM \\ JURNAL MAGISTER MANAJEMEN \\ UNIVERSITAS MATARAM \\ September 2016}

Hipotesis ini diajukan untuk mengetahui pengaruh signifikan secara parsial variabel ekuitas merek dan kualitas pelayanan terhadap minat beli ulang konsumen AXA Mandiri Mapan di kota Mataram. Dalam pengujian ini dilakukan dengan uji $t$ dan membandingkan antara $t_{\text {hitung dengan } t} t_{\text {tabel }}$ yang dapat dilihat pada tabel berikut:

Tabel Hasil Uji Regresi Linear Berganda Secara Parsial

\begin{tabular}{ccccc}
\hline Model & $\boldsymbol{\beta}$ & $\mathbf{t}$ & Sig & Keterangan \\
\hline Ekuitas Merek $\left(\mathrm{X}_{1}\right)$ & 0,857 & 8,842 & 0,00 & Signifikan \\
& & & 0 & \\
Kualitas Pelayanan $\left(\mathrm{X}_{2}\right)$ & 0,296 & 3,513 & 0,00 & Signifikan \\
& & & 1 & \\
\hline
\end{tabular}

Sumber: Data Primer.

1) Uji Hipotesis 1 (Pengaruh Ekuitas Merek)

Dari tabel di atas terlihat bahwa hasil pengujian hipotesis Ekuitas Merek menunjukkan nilai $t_{\text {hitung }}$ sebesar $\mathbf{8 , 8 4 2}$ yang lebih besar dari nilai $t_{\text {tabel }}$ dengan a $0,05=$ 1,984. Kenyataan ini berarti bahwa hipotesis observasi (Ho) ditolak dan menerima hipotesis alternatif (Ha). Dengan demikian dapat disimpulkan bahwa Ekuitas Merek berpengaruh secara positif dan signifikan terhadap minat beli ulang konsumen AXA Mandiri Mapan di kota Mataram.

AXA Mandiri harus terus meningkatkan tingkat ekuitas merek serta memperhatikan kebutuhan konsumen pada layanan asuransi agar kualitas dan minat beli masyarakat meningkat. Kedua variabel ini saling terkait dan searah artinya ekuitas merek mempengaruhi tingkat minat beli ulang konsumen. Semakin tinggi ekuitas merek akan semakin tinggi pula tingkat minat beli ulang konsumen AXA Mandiri Mapan di Kota Mataram.

Variabel Ekuitas Merek memiliki nilai sebesar 0,634 berdasarkan Standardized Coeficient Beta artinya variabel yang paling berpengaruh kuat atau dominan adalah ekuitas merek. Perusahaan perlu melakukan persaingan dalam meningkatkan ekuitas merek, karena ekuitas merek sangat penting untuk memperkuat reputasi perusahaan. Perusahaan yang mampu mengembangkan preferensi merek akan mampu mempertahankan serangan dari para pesaing.

Menurut Retnawati (2003), merek menjadi sangat strategis bagi perusahaan dengan manfaat yang diberikan bagi penjual dan pembeli, pengelolaan merek yang efektif dimungkinkan dapat mempertahankan kesetiaan konsumen yang ada, serta dapat untuk menghambat serangan pesaing dan membantu memfokuskan program pemasaran. Keegan et al., (1995:331) mengemukakan bahwa preferensi merek terbaik dapat memberikan jaminan kualitas bagi konsumennya. Sebagai perusahaan asuransi kepercayaan serta reputasi perusahaan merupakan salah satu modal dasar AXA Mandiri dapat bersaing dan meningkatkan minat beli ulang konsumen atas produknya. Kedua variabel ini saling terkait dan searah artinya ekuitas merek mempengaruhi tingkat minat beli ulang konsumen. Semakin tinggi ekuitas merek akan semakin tinggi pula tingkat minat beli ulang konsumen AXA Mandiri Mapan di kota Mataram. 
2) Uji Hipotesis 2 (Pengaruh Kualitas Pelayanan)

Dari Tabel 4.16 terlihat bahwa hasil pengujian hipotesis Kualitas Pelayanan menunjukkan nilai $t$ hitung sebesar 3,513 yang lebih besar dari nilai $t$ tabel dengan a 0,05= 1,984. Kenyataan ini berarti bahwa hipotesis observasi (Ho) ditolak dan menerima hipotesis alternatif (Ha). Dengan demikian dapat disimpulkan bahwa Kualitas Pelayanan berpengaruh secara positif dan signifikan terhadap minat beli ulang konsumen AXA Mandiri Mapan di kota Mataram. Kedua variabel ini saling terkait dan searah artinya kualitas pelayanan yang ada pada AXA Mandiri Mapan dapat mempengaruhi tingkat minat beli ulang konsumen AXA Mandiri Mapan di kota Mataram. Semakin tinggi kualitas pelayanan pada konsumen, akan semakin tinggi pula minat beli ulang konsumen.

Sikap pelanggan mengenai kinerja perusahaan yang terdiri dari kinerja produk, kinerja pelayanan dan kinerja sumber daya manusia mempengaruhi niat pembelian ulang polis asuransi jiwa melalui kepuasan nasabah. Perusahaan asuransi akan dapat diwujudkan dengan memperhatikan kualitas layanan nasabah. Kualitas layanan produk yang lebih akan mendorong pelanggan untuk membeli produk dan menggunakan solusi yang perusahaan tawarkan.

3) Uji Hipotesis 3 (Pengaruh Simultan Ekuitas Merek dan Kualitas Pelayanan)

Variabel bebas secara bersama-sama diuji dengan menggunakan uji F. Hasil perhitungan regresi secara simultan dijelaskan pada tabel berikut ini:

Tabel Hasil Uji Regresi Linear Berganda Secara Simultan

\begin{tabular}{lccccc}
\hline \multicolumn{1}{c}{ Model } & $\begin{array}{c}\text { Sum of } \\
\text { Squares }\end{array}$ & $d f$ & Mean Square & F & Sig. \\
\hline $\begin{array}{l}\text { Regressio } \\
\mathrm{n}\end{array}$ & 29,466 & 2 & 14,733 & 63,371 & 0,000 \\
Residual & 21,854 & 94 & 0,232 & & \\
Total & 51,320 & 96 & & & \\
\hline
\end{tabular}

Sumber: Data Primer.

Hasil perhitungan statistik menunjukkan nilai $\mathrm{F}_{\text {hitung }}$ sebesar 63,371 dengan taraf signifikan 0,000. Apabila dibandingkan dengan $F_{\text {tabel }}$ dengan $0,05=3,09$ artinya hipotesis observasi (Ho) ditolak dan menerima hipotesis alternatif (Ha). Dengan demikian dapat disimpulkan bahwa ekuitas merek dan kualitas pelayanan berpengaruh positif dan signifikan secara simultan terhadap minat beli ulang konsumen AXA Mandiri Mapan di kota Mataram. Hal ini menunjukkan bahwa ekuitas merek yang baik dan kualitas pelayanan yang tinggi dapat mempengaruhi tingkat minat beli ulang konsumen AXA Mandiri Mapan di kota Mataram.

Taylor dan Cosenza (2002) yang menyatakan bahwa perilaku pembelian ulang yang dilakukan pelanggan banyak dipengaruhi oleh beberapa hal di antaranya merek produk dan layanan yang diberikan oleh perusahaan. Terdapat pengaruh dominan dari kedua variabel bebas yaitu ekuitas merek. Dari tabel nampak nilai yang tertinggi dari variabel bebas yaitu ekuitas merek kemudian diikuti oleh kualitas pelayanan. Terlihat nilai koefisien regresi pada variabel Ekuitas Merek sebesar 0,857 artinya variabel yang paling berpengaruh kuat atau dominan adalah ekuitas merek karena merupakan 
pendukung produsen atau penjual dari suatu produk, yang dapat menggambarkan dan memberikan bukti mengenai janji produsen untuk menyampaikan kesimpulan sifat, manfaat, nilai konsumen dan jasa spesifik secara konsisten kepada konsumen.

Koefisien determinasi $\left(\mathrm{r}^{2}\right)$ untuk mengukur seberapa besar kemampuan variabel independen (ekuitas merek dan kualitas pelayanan) dalam menerangkan variabel dependen (minat beli ulang konsumen).

Tabel Koefisien Determinasi

\begin{tabular}{ccccc}
\hline Model & $\boldsymbol{R}$ & $\boldsymbol{R}$ Square & $\begin{array}{c}\text { Adjusted } \boldsymbol{R} \\
\text { Square }\end{array}$ & $\begin{array}{c}\text { Std. Error of } \\
\text { the Estimate }\end{array}$ \\
\hline 1 & $0,758^{\mathrm{a}}$ & 0,574 & 0,565 & 0,48217 \\
\hline Sumber: Data Primer. & & &
\end{tabular}

Dalam tabel di atas nampak $R$ square sebesar 0,574 yang berarti variabel ekuitas merek dan kualitas pelayanan mempengaruhi minat beli ulang konsumen terhadap AXA Mandiri Mapan di kota Mataram sebesar 57,40 persen, selebihnya ditentukan oleh variabel lain di luar model penelitian sebesar 42,60 persen.

5. Kesimpulan dan Rekomendasi

Berdasarkan analisis hasil dan pembahasan yang telah dilakukan mengenai Pengaruh Ekuitas Merek dan Kualitas Layanan terhadap Minat Beli Ulang Konsumen AXA Mandiri Mapan di Kota Mataram, dapat diambil beberapa kesimpulan sebagai berikut:

1) Ekuitas Merek berpengaruh terhadap Minat Beli Ulang Konsumen AXA Mandiri Mapan di kota Mataram.

2) Kualitas Pelayanan berpengaruh terhadap Minat Beli Ulang Konsumen AXA Mandiri Mapan di kota Mataram.

3) Ekuitas merek dan Kualitas Pelayanan secara simultan berpengaruh terhadap Minat Beli Ulang Konsumen AXA Mandiri Mapan di kota Mataram.

Hasil analisis dan pembahasan penelitian yang telah dilakukan memberikan saran bagi perusahaan dimana perusahaan harus memperhatikan nilai ekuitas merek perusahaan agar dapat terus bersaing di pasar karena ekuitas merek sangat penting untuk memperkuat reputasi perusahaan, dimana produk perusahaan asuransi manfaatnya tidak langsung dirasakan dan membutuhkan kepercayaan serta minat beli ualng konsumen atas produk perusahaan akan meningkat. Selanjutnya perusahaan harus meningkatkan kualitas pelayanan perusahaan terhadap konsumennya, perusahaan asuransi akan dapat diwujudkan dengan memperhatikan kualitas layanan nasabah, sehingga mendorong pelanggan untuk membeli produk dan menggunakan solusi yang ditawarkan perusahaan.

Penelitian ini hanya meneliti dua variabel independen yaitu ekuitas merek dan kualitas pelayanan sebagaimana hasil analisis penelitian berkontribusi sebesar 47,40 persen, sedangkan sisanya sebesar 52,60 persen merupakan kontribusi variabel lain yang tidak diteliti dalam penelitian ini. Nilai persentase kontribusi variabel lain terhadap minat beli ulang produk asuransi AXA Mandiri cukup besar, sehingga diharapkan penelitian selanjutnya dapat menganalisis variabel lain tersebut. Responden penelitian ini hanya nasabah AXA Mandiri di kota Mataram sehingga diharapkan penelitian selanjutnya dapat meneliti dengan lingkup responden yang lebih luas. 


\section{Daftar Pustaka}

Bancassurance, Academi. 2011. Product Knowledge FA Basic Training. Jakarta : PT. Axa Mandiri,Tbk.

Darwin, Steven and Sondang, Yohanes. 2014. Analisis Pengaruh Kualitas Layanan Terhadap Loyalitas Pelanggan Dengan Kepuasan Dan Kepercayaan Pelanggan Sebagai Variabel Interverning Pada Asuransi Jiwa Manulife Indonesia-Surabaya. Jurnal Manajemen Pemasaran Petra, Vol 2, No.1 (2014).

Dwityanti, Esthi. 2008. Analisis Faktor-Faktor Yang Mempengaruhi Minat Beli Konsumen Terhadap Layanan Internet Banking Mandiri Studi Kasus Pada Karyawan Departemen Pekerjaan Umum Jakarta. Semarang : Universitas Diponegoro.

Engel, FJ. Blackwell, DR and Miniard, PW. 2010. Perilaku Konsumen. Jilid Satu. Jakarta : Binarupa Aksara Publisher.

Fihartini, Yuniarti. 2009. Pengaruh Kepercayaan Dan Kualitas Layanan Terhadap Loyalitas Nasabah Asuransi Di Bandar Lampung. Lampung : Universitas Lampung.

Ghozali, Imam. 2007. Aplikasi Analisis Multivariat dengan Program SPSS. Edisi Keempat. Semarang : Universitas Diponegoro.

Hartono, Setyo. Djoko. 2008. Analisis Pengaruh Kualitas Pelayanan Terhadap Tingkat Kepuasan Peserta Askes Melalui Pendekatan Dimensi Servqual. Jurnal Universitas Muhammadiyah Semarang II.50-60.

Kurniawan, Iwan. SB, Suryono dan Dwiyanto, MB. 2008. Analisis Faktor-Faktor yang Mempengaruhi Minat Beli Ulang Produk serta Dampaknya terhadap Loyalitas Pelanggan. Jurnal Studi Manajemen dan Organisasi IV.27-42.

Ratih, Brahma Aju. Ida. 2006. Pengaruh Kinerja Produk, Pelayanan dan Sumberdaya Manusia Terhadap Niat Pembelian Ulang Melalui Citra Perusahaan dan Kepuasan Pelanggan PT Asuransi Jiwasraya.Ekuitas 1411-0393 Akreditasi No.55a/DIKTI/Kep/2006.

Rahma, Sheilla Eva. 2007. Analisis Pengaruh Kualitas Layanan dan Citra Merek terhadap Minat Beli. Semarang : Universitas Diponegoro.

Rizan, M dan Arrasyid, H. 2008. Analisis Asosiasi Merek, Nilai Produk dan Kualitas Pelayaan, serta Pengaruhnya terhadap Kepuasan dan Loyalitas Konsumen Sepeda Motor Di Bekasi. Jurnal Siasat Bisnis.12s9-147.

Schiffman, L and Kanuk, LL. 2008. Perilaku Konsumen. Edisi Ketujuh. Jakarta : PT. Macanan Jaya Cemerlang.

Sanjaya, Edwin. 2009. Pengaruh Brand Equity Terhadap Purchase Intention Melalui Brand Preference Pada Produk PT. Sunlife Financial Di Surabaya. Surabaya.

Ujianto dan Abdurachman. 2003. Analisi Faktor-Faktor yang Menimbulkan Kecendrungan Minat Beli Konsumen Sarung Studi Perilaku Konsumen Sarung Di Jawa Timur. Jurnal Manajemen \& Kewirausahaan Vol. 6, No. 1.34-53. 